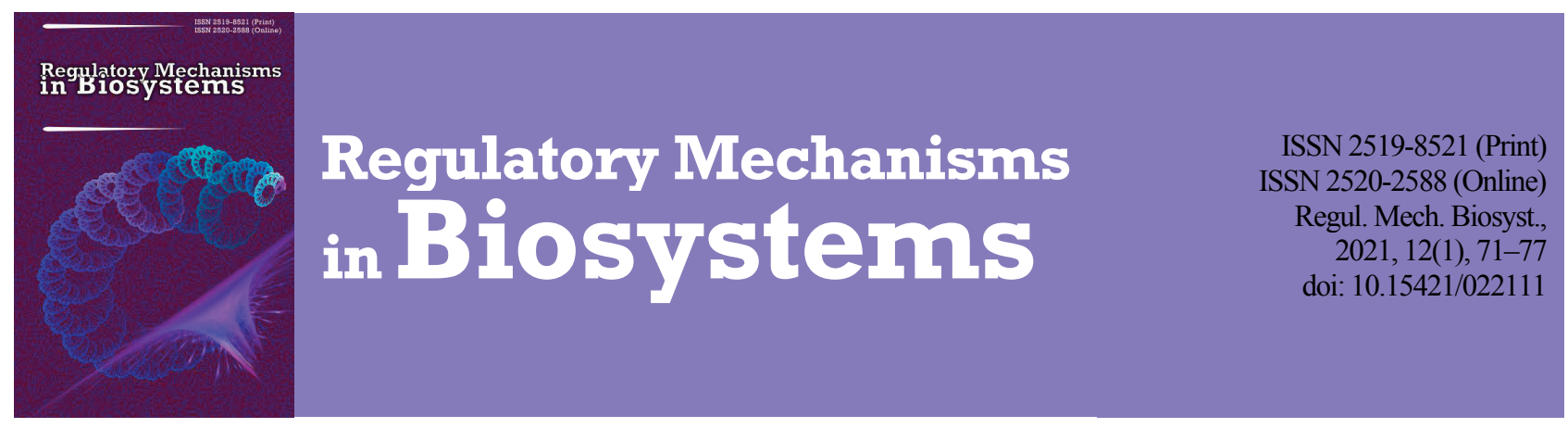

\title{
Biochemical characterization of fruits of Lycium spp. in Ukraine
}

\author{
M. Zhurba*, O. Vergun*, S. Klymenko*, I. Szot** \\ *M. M. Gryshko National Botanical Garden of Ukraine, National Academy of Sciences, Kyiv, Ukraine \\ **University of Life Sciences, Lublin, Poland
}

Article info

Received 27.01.2021

Received in revised form 22.02 .2021

Accepted 24.02.2021

M. M. Gryshko National Botanical Garden of Ukraine National Academy of Sciences,

Timiryazevska st., 1, Kyiv, 01014,

Ukraine. Tel.: +38-067-367-65-42

E-mail:zhurbamikhail@gmail.com

University of Life Sciences,

Akademicka st. 13, Lublin, 20-033,

Poland. Tel: + 38-815-24-71.

E-mail: szoti@autograf.pl

\section{Zhurba, M., Vergun, O., Klymenko, S., \& Szot, I. (2021). Biochemical characterization of fruits of Lycium spp. in Ukraine. Regulatory Mechanisms in Biosystems, 12(1), 71-77. doi:10.15421/022111}

Fruits of Lycium possess therapeutic properties due to which they are used in traditional and folk medicine and can be used as a kind of functional food. The objective of this study was to evaluate the biochemical characterization of Lycium L. (L. barbarum L., $L$. chinense Mill. and L. truncatum Y. C. Wang) fruits for 16 cultivars and varieties from the collections in the M. M. Gryshko National Botanical Garden of NAS of Ukraine (Kyiv). This study was aimed at determining the concentration of nutrients in the Lycium fruits. Individual genotypes of three Lycium species: L. barbarum, L.chinense, and L. truncatum, differed in such features as the content of dry matter, sugars, vitamin $C, \beta$-carotene, acidity, and tannins in the fruit. Fruits of Lycium spp. are a valuable source of nutrients such as vitamin $\mathrm{C}\left(4.38-121.0 \mathrm{mg} 100 \mathrm{~g}^{-1} \mathrm{FW}\right), \beta$-carotene content $(1.45-5.52 \%)$, and tannin $(0.12-1.34 \%)$. The sugar content (13.83$20.87 \%)$ and acidity of the fruit $(0.23-4.62 \%)$ meet the consumers' requirements for fresh fruit. The cultivar Amber Sweet $(L$. chinense) had fruits of which the similarities between biochemical characteristics of different studies genotypes were the lowest. The cv. Amber Sweet was characterized by fruit with high sugar content, very high vitamin C content, average acid content, low tannins and $\beta$-carotene content, and the lowest dry matter content. Furthermore, a distinctive feature of the other tested genotypes was the yellow colour of the fruit. The data obtained can be used for further selective work.

Keywords: goji berry; cultivars; varieties; fruits; biochemical composition

\section{Introduction}

Some neglected and underutilized species of plants, namely, Cydonia oblonga Mill. (Monka et al., 2014), Sambucus nigra (Horčinová Sedláčková et al., 2018, 2019), Cornus mas L. (Klymenko et al., 2019), Aronia mitschurinii A. K. Skvortsov \& Maitul. (Vinogradova et al., 2020), containing biologically active compounds with human health-enhancing properties known for hundreds or thousands of years have experienced a renaissance and have aroused interest in the world of science in the last decade (Klymenko et al., 2017; Konarska, 2018). It is also very important to introduce and grow lesser-known and non-traditional plant species, namely, Pseudocydonia sinensis (Thouin) C. K. Schneid. (Monka et al., 2014; Grygorieva et al., 2020), Castanea sativa Mill. (Grygorieva et al., 2017), Ziziphus jujuba Mill. (Ivanišová et al., 2017), and Elaeagnus multiflora Thunb., Mespilus germanica L., Diospyros virginiana L. (Grygorieva et al., 2018a, 2018b, 2018c). Species of the genus Lycium L. also belong to this group of plants, since they have long been used in Chinese traditional and folk herbal medicine due to their therapeutic properties.

The genus Lycium includes about 92(97) species, of which 35 plant species are used for food or as medicines (Yao et al., 2018). Of these, only the fruits of two species from east Asia, namely L. barbarum L. and L. chinense Mill. have been consumed in Chinese medicine in the capacity of 'superfood' for over 2000 years (Amagase \& Farnsworth, 2011; Yao et al., 2018).

The goji fruits are used in fresh and dried condition and from them are prepared juices, wine, preserves, the substitute of tea made of leaves, processed as tinctures, powders, tablets, consumed in soups, as porridge with rice and added to numerous meat and vegetable dishes (Potterat, 2010; Yao et al., 2018). The Lycium fruits contain phenolics, flavonoids, organic acids, and fatty acids (Wang et al., 2010; Mikulic-Petkovsek et al., 2012) and are also high in vitamins such as thiamine, riboflavin, and vitamin C (Donno et al., 2014; Niro et al., 2017), carotenoids (Chang et al., 2015), polysaccharides (Luo et al., 2004; Wang et al., 2010), betaine (Xie et al., 2001; Lee et al., 2014; Qian et al., 2017), and taurine (Potterat, 2010), have high mineral concentrations (Grembecka \& Szefer, 2013). With such a rich biochemical composition, goji fruits are very widely used in pharmacology due to their high anti-cancer (Tang et al., 2012; Cumaoglu et al., 2018), anti-hyperglycemic (Potterat, 2010; Wojdyło et al., 2018), anti-inflammatory (Liu et al., 2015; Wang et al., 2017), anti-aging properties (Chang et al., 2015; Wojdyło et al., 2018), and antioxidant properties (Illić et al., 2020). Not only do the fruits contain biologically active substances, but also other parts of plants, especially leaves (Chen et al., 2020; Grygorieva et al., 2020; Szot et al., 2020). The nutritional properties of Lycium fruits grown in Ukraine have not been investigated. Therefore, the present study aimed to investigate for the first time, the biochemical composition of the fruits of Lycium spp. grown in Ukraine.

\section{Materials and methods}

Plants of Lycium (Fig. 1) were grown in M. M. Gryshko National Botanical Garden of NAS of Ukraine in Kyiv (NBG) from seeds or cuttings obtained from China, France, Slovak Republic, and other botanical gardens of Ukraine. There 16 genotypes were investigated in an experimental study 2019, including three species (Lycium barbarum, L. chinense, L. truncatum) and 8 cultivars and 8 varieties (LB01-LB03, LC01-LC05). Samples were marked as LB (L. barbarum), LC (L. chinense).

The dry matter determination was conducted according to the procedure described by Ogbonna et al. (2016). The method is based on the measurement of decrease in mass of air-dry matter. Fixed mass (approximately $5 \mathrm{~g}$ ) of fresh shredded raw fruit was dried in aluminum containers at $105{ }^{\circ} \mathrm{C}$ in an oven till constant weight. Before this procedure, the cleaned containers were dried for $30 \mathrm{~min}$ at $105^{\circ} \mathrm{C}$ and cooled in a desiccator and then the samples weighed. Results were given in percent. The procedure was conducted with fresh raw material. In this case, $4 \mathrm{~g}$ of 
shredded raw fruit was mixed with distilled water in a volumetric flask $(100 \mathrm{~mL})$ and boiled till $70{ }^{\circ} \mathrm{C}$. After cooling down, $1.5 \mathrm{~mL}$ of $30 \%$ lead acetate was added to the mixture for 12 hours. After this, $1 \mathrm{~mL}$ of phosphate buffer was added to the mixture, which was shaken. The obtained solution was left for $30 \mathrm{~min}$. After filtration, $50 \mathrm{~mL}$ of extract was mixed with $8 \mathrm{~mL}$ of $20 \% \mathrm{HCl}$ and heated to $70{ }^{\circ} \mathrm{C}$. After cooling, neutralization of plant extracts with $12 \% \mathrm{NaOH}$ solution was conducted. $3 \mathrm{~mL}$ of plant extract was mixed with $6 \mathrm{~mL}$ Fehling's reactive solution and boiled for 6 min. Before titration with $0.01 \mathrm{~N} \mathrm{KMnO}_{4}, 10 \mathrm{~mL}$ of iron-ammonium alum was added. Results are given in percent (Krishchenko, 1983).

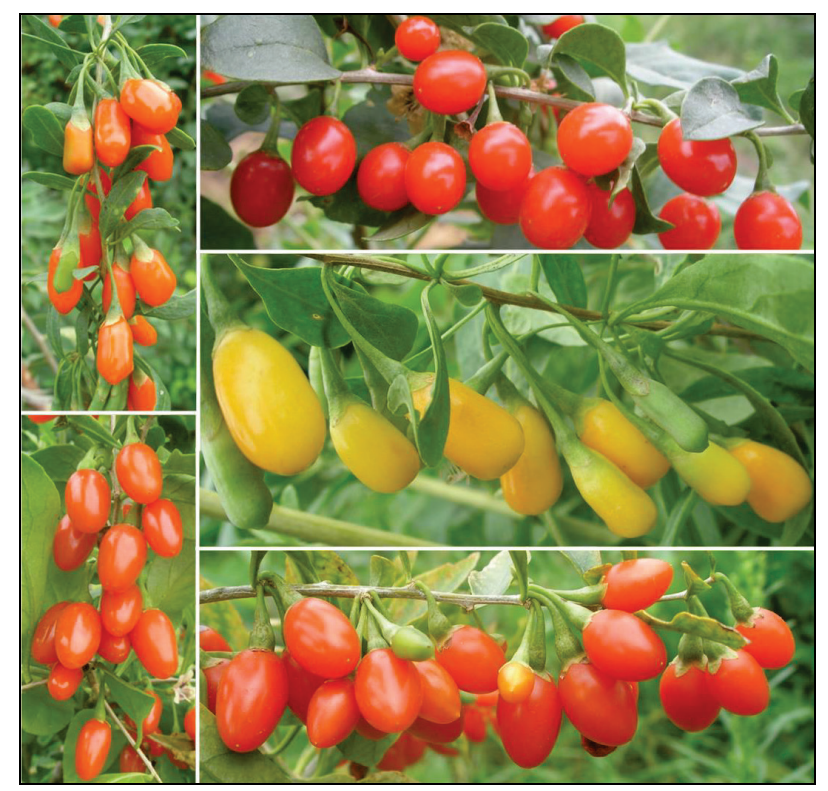

Fig. 1. Fruits of Lycium spp. of the NBG collection

The reducing properties of ascorbic acid underlie this method. $2 \mathrm{~g}$ of fresh mass was mixed with $50 \mathrm{~mL}$ of the acid mixture $(1 \% \mathrm{HCl}$ and $2 \%$ oxalic acid) and homogenized. The obtained extracts were put into darkness in $20 \mathrm{~min}$ and after this filtered with paper. $10 \mathrm{~mL}$ of obtained filtrate was poured into another flask that was titrated by the $0.001 \mathrm{~N}$ solution of sodium 2.6-dichlorophenolindophenolate. Results are given in $\mathrm{mg} / 100 \mathrm{~g}$ FW (Krishchenko, 1983).

The determination of $\beta$-carotene was conducted in gasoline Galosh extracts. $1 \mathrm{~g}$ of absolutely dried raw mass was extracted in $20 \mathrm{~mL}$ of gasoline Galosh for 12 hours. Also, $0.2 \mathrm{~g}$ of aluminum oxide and $0.05 \mathrm{~g}$ of calcium oxide were added to the extracts to connect pigment. After filtration, the density of extracts was measured on a spectrophotometer Unico UV 2800 at the wavelength $440 \mathrm{~nm}$. Absorbance was measured with pure gasoline Galosh. The solution of $\mathrm{K}_{2} \mathrm{Cr}_{2} \mathrm{O}_{7}$ was used as standard, the density determined as $0.00416 \mathrm{mg}$ of carotene in $1 \mathrm{~mL}$ (Pleshkov, 1985).

The method of determination of titratable acidity is based on sodium hydroxide titration of free acids in water plant extracts. $5 \mathrm{~g}$ of the fresh mass of sample was mixed with approximately $70 \mathrm{~mL}$ of distilled water in a volumetric flask $(100 \mathrm{~mL})$. Flasks were placed in a water bath at $80^{\circ} \mathrm{C}$ for $15 \mathrm{~min}$ with periodic shaking. After cooling, the flasks were filled with water to $100 \mathrm{~mL}$. After filtration, $50 \mathrm{~mL}$ of extract was titrated with $0.1 \mathrm{~N}$ $\mathrm{NaOH}$ in presence of phenolphthalein (two drops). Obtained results were given in percent (Krishchenko, 1983).

For determination of tannin content $5 \mathrm{~g}$ of fresh mass was mixed with distilled water in volumetric flasks $(100 \mathrm{~mL})$ and put into the water bath for 2 hours at $80^{\circ} \mathrm{C}$. After the cooling procedure, distilled water was added to flask content till $100 \mathrm{~mL}$ and filtered. $10 \mathrm{~mL}$ of obtained filtrate was poured into another flask $(1 \mathrm{~L})$, and $750 \mathrm{~mL}$ of water, and $25 \mathrm{~mL}$ of indigo carmine solution were added. The obtained mixture was titrated by $0.1 \mathrm{~N} \mathrm{KMnO}_{4}$. At the same time the same procedure was conducted but with $2 \mathrm{~g}$ of activated carbon. The difference between sample titration with activated carbon and without corresponds to $\mathrm{KMnO}_{4}$ volume used for oxidation of tannins in this solution (Krishchenko, 1983).

Basic statistical analyses were performed using PAST 2.17 (Norway, 2001); the results are expressed as mean values of three replications \pm standard deviation (SD); hierarchical cluster analyses of similarity between phenotypes were computed on the basis of the Bray-Curtis similarity index. Data were analysed with ANOVA test and differences between means compared through the Tukey-Kramer test $(\mathrm{P}<0.05)$.

\section{Results}

One of the numerous biochemical parameters that demonstrate the value of plant raw material is dry matter content. The data in this study concerning dry matter content ranged between $13.8 \%$ (L. chinense $\mathrm{cv}$. Amber Sweet) and 20.9\% (L. barbarum LB03, Fig. 2).

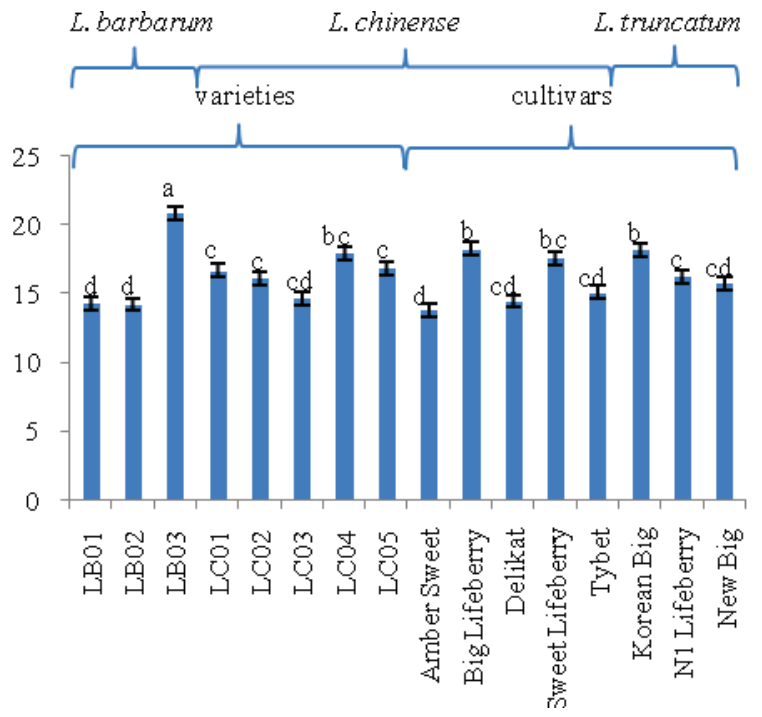

Fig. 2. Content of dry matter of fruits of species of the genus Lycium cultivars and varieties $(\%$, means in each column followed by different letters are not significantly different, $\mathrm{P}<0.05$ )

The content of sugars, as is known, is an important characteristic of fruit taste. The total sugar contents of the 16 Lycium fruits samples were determined from $3.6 \%$ (L. truncatum cv. New Big) to $11.7 \%$ (L. truncatum cv. Korean Big, Fig. 3). In this respect, varieties and cultivars of $L y$ cium varied greatly.

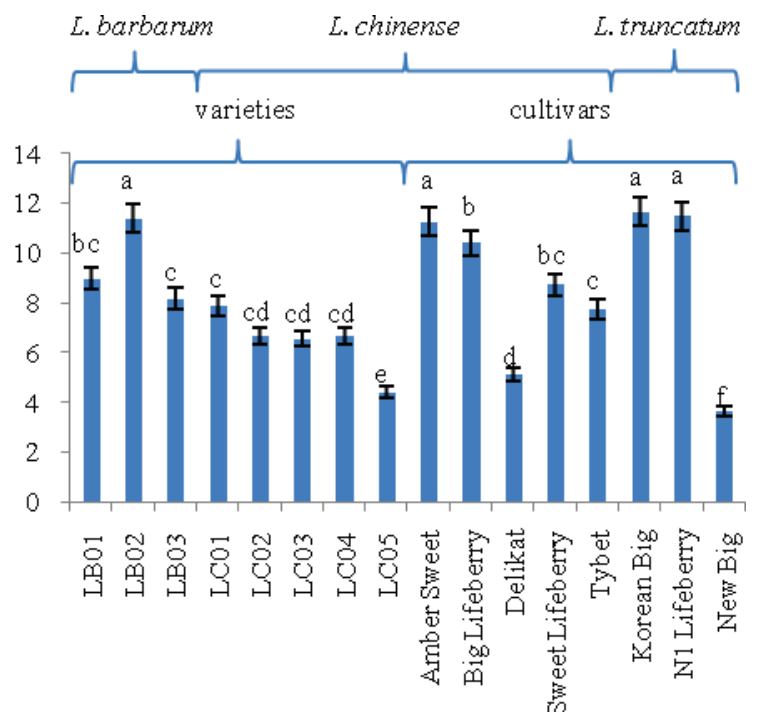

Fig. 3. Total sugar content of fruits of species of the genus Lycium cultivars and varieties $(\%$, means in each column followed by different letters are not significantly different, $\mathrm{P}<0.05$ )

Significant differences were found in the concentration of vitamin $\mathrm{C}$ between the species, cultivars, and varieties in this study. The vitamin $\mathrm{C}$ content ranged between 4.38 (L. truncatum cv. New Big) and $121.0 \mathrm{mg} \cdot 100 \mathrm{~g}^{-1}$ (L. chinense cv. Amber Sweet, Fig. 4). The fruits of L. truncatum had the lowest vitamin $\mathrm{C}$ content in comparison with other species. 


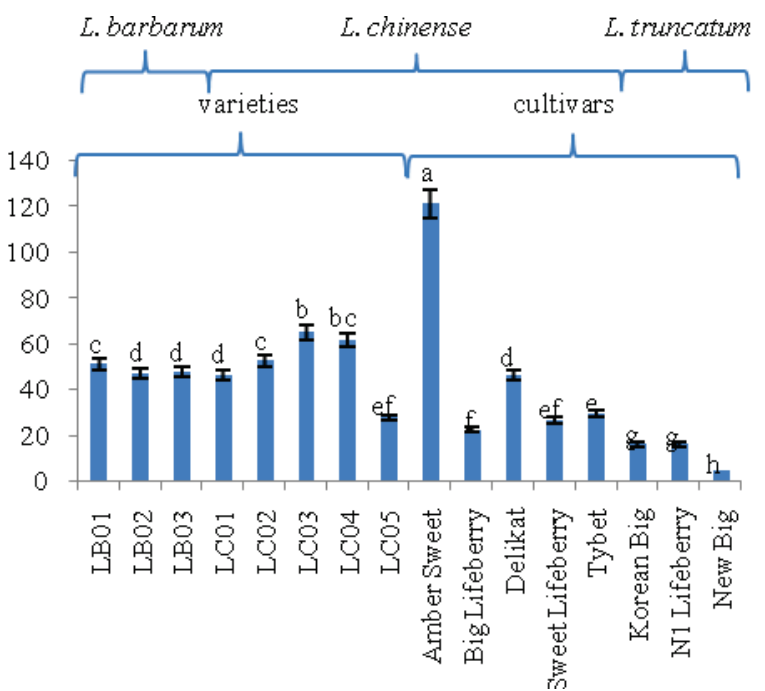

Fig. 4. Vitamin $C$ of fruits of species of the genus Lycium cultivars and varieties $\left(\mathrm{mg} \cdot 100 \mathrm{~g}^{-1} \mathrm{FW}\right.$, means in each column followed

by different letters are not significantly different, $\mathrm{P}<0.05$ )

Alongside ascorbic acid content, $\beta$-carotene is not a less important vitamin with high biological activity. The total $\beta$-carotene content of Lycium fruits is recorded in Figure 5. The lowest content was observed in L. chinense cv. Amber Sweet $\left(1.45 \mathrm{mg} \cdot 100 \mathrm{~g}^{-1} \mathrm{FW}\right)$, while $L$. barbarum (LB02) (5.52 mg $100 \mathrm{~g}^{-1} \mathrm{FW}$ ) exhibited the highest carotene content. The lowest content of this pigment in fruits of $L$. chinense cv. Amber Sweet is explained by the fact that fruits of this variety are yellow.

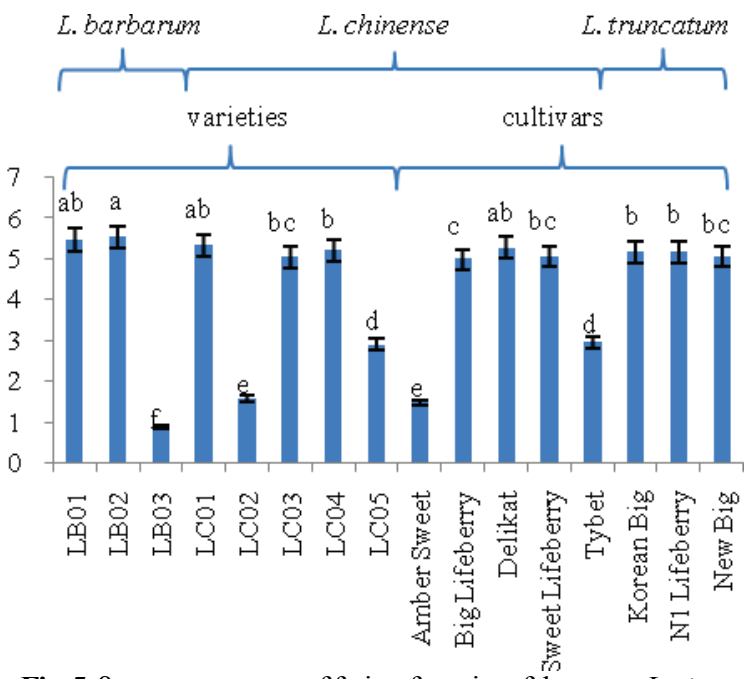

Fig. 5. $\beta$-carotene content of fruits of species of the genus Lycium cultivars and varieties $\left(\mathrm{mg} \cdot 100 \mathrm{~g}^{-1} \mathrm{FW}\right.$, means in each column

followed by different letters are not significantly different, $\mathrm{P}<0.05$ )

The titratable acidity of all fruits ranged $0.23-4.62 \%$ (Fig. 6). The fruits of $L$. chinensis (cv. Sweet Lifeberry) were the most acidic with a titratable acidity value of $4.62 \%$ while the fruits of $L$. barbarum (LB03) were the least acidic with a titratable acidity value of $0.23 \%$. The titratable acidity values of $L$. barbarum (LB01, LB02, LB03) were characterized by low titratable acidity $(<0.8 \%)$, which showed that $L$. barbarum genotypes had a better taste than other genotypes tested.

The tannin content of 16 Lycium fruits samples is presented in Figure 7. The relatively higher content of tannin was recorded in Lycium fruits samples $L$. chinensis cv. Sweet Lifeberry, L. truncatum cv. N1 Lifeberry, and LC05 $(1.34 \%, 1.34 \%$, and $1.12 \%$, respectively) while the lowest content of tannin was recorded in samples $L$. chinensis cv. Amber Sweet, $L$. chinensis cv. Tybet, and L. barbarum LB01 $(0.29 \%, 0.24 \%$, and $0.12 \%$, respectively). All other samples had tannin content ranging from $0.34 \%$ to $0.77 \%$. Correlation analysis was used to explore the relationships between the biochemical characteristics measured for all fruit extracts from Lycium cultivars and varieties (Table 1). Strong positive correlation was found only between tannin content and titratable acidity $(r=$
$0.729, \mathrm{P}<0.001)$. Weak positive correlation was found between $\beta$ carotene content and tannin $(\mathrm{r}=0.219, \mathrm{P}<0.05), \beta$-carotene and titratable acidity $(\mathrm{r}=0.246, \mathrm{P}<0.05)$, total sugars content and titratable acidity $(\mathrm{r}=$ $0.246, \mathrm{P}<0.05)$, and dry matter and tannins $(\mathrm{r}=0.421, \mathrm{P}<0.01)$.

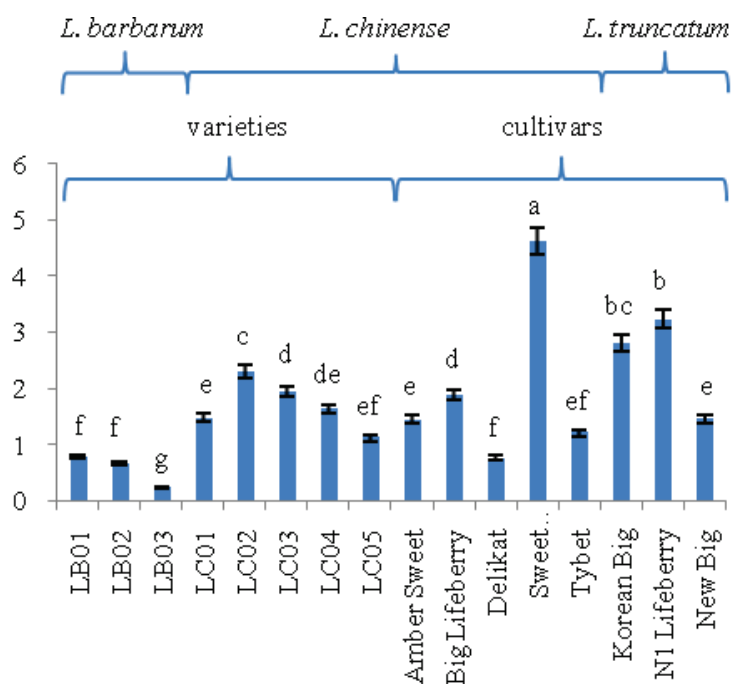

Fig. 6. Titratable acidity content of fruits of species of the genus Lycium cultivars and varieties $(\%$, means in each column followed by different letters are not significantly different, $\mathrm{P}<0.05$ )

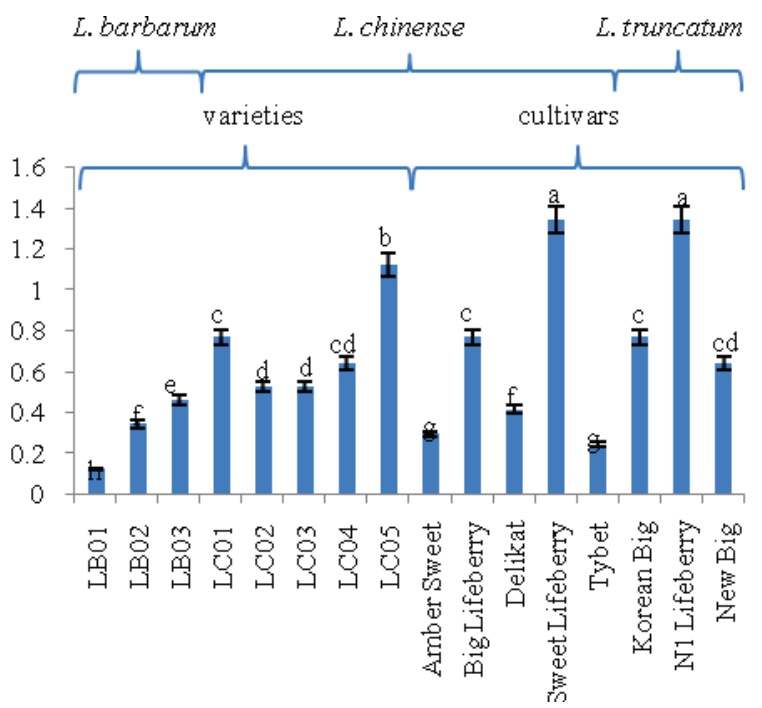

Fig. 7. Tannins content of fruits of species of the genus Lycium cultivars and varieties $(\%$, means in each column followed by different letters are not significantly different, $\mathrm{P}<0.05$ )

Table 1

Correlation coefficients of a linear relationship between the biochemical characteristics of tested Lycium genotypes

\begin{tabular}{lcccccc}
\hline \multicolumn{1}{c}{ Parameter } & $\begin{array}{c}\text { Dry } \\
\text { matter }\end{array}$ & $\begin{array}{c}\text { Total sugar } \\
\text { content }\end{array}$ & $\begin{array}{c}\text { Ascorbic } \\
\text { acid }\end{array}$ & $\begin{array}{c}\beta- \\
\text { carotene }\end{array}$ & $\begin{array}{c}\text { Titrable } \\
\text { acidity }\end{array}$ & Tannins \\
\hline Dry matter & 1 & 0.030 & $-0.370^{*}$ & -0.208 & 0.166 & $0.421^{* *}$ \\
Total sugar & 0.030 & 1 & 0.159 & 0.074 & $0.264^{*}$ & 0.026 \\
content & & & & $-0.406^{* *}$ & $-0.288^{*}$ & $-0.505^{* *}$ \\
Ascorbic acid & $-0.370^{*}$ & 0.159 & 1 & 1 & $0.246^{*}$ & $0.219^{*}$ \\
$\beta$-carotene & $-0.208^{*}$ & 0.074 & $-0.406^{* *}$ & 1 & 1 & 0.729 \\
Titrable acidity & 0.166 & $0.264^{*}$ & $-0.288^{*}$ & $0.246^{*}$ & 1 & 1 \\
Tannins & $0.421^{* *}$ & 0.026 & $-0.505^{* *}$ & $0.219^{*}$ & $0.729^{* * *}$ & 1 \\
\hline
\end{tabular}

Note: ${ }^{*}-\mathrm{P}<0.05, * *-\mathrm{P}<0.01,{ }^{* * *}-\mathrm{P}<0.001$

Hierarchical cluster analysis can be used as useful tools for screening samples to study the similarities between biochemical characteristics of different plants. Hierarchical cluster analysis biochemical characterization was used to evaluate the collected 16 genotypes of Lycium spp (Fig. 8). A comparison clearly shows the different genotypes and grouping and the significant differences between them. The similarity coefficient for different genotypes was in the range $0.55-0.95$. 


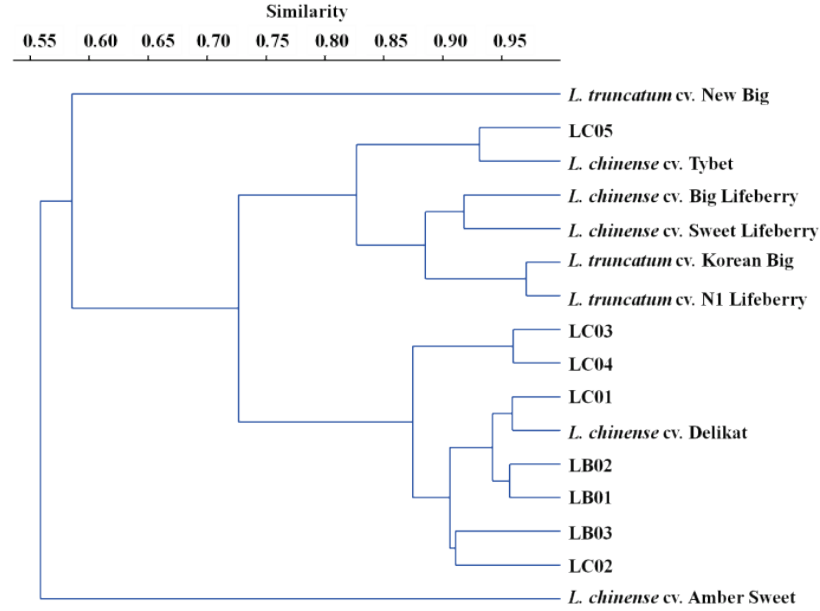

Fig. 8. Dendrogram from hierarchical cluster analysis of the biochemical characterization of 16 genotypes of Lycium spp.

The dendrogram that was generated by cluster analysis showed four well-defined groups. The first and fourth clusters include only one sample (L. truncatum cv. New Big and L. chinense cv. Amber Sweet) with a similarity value of 0.57 and 0.55 , respectively. The first cultivar had the lowest total sugar and ascorbic acid content. The second cultivar was distinguished by the highest content of ascorbic acid and the lowest dry matter. The second cluster includes one variety and 5 cultivars, namely, LC05 (L. chinense) and Tybet, Big Lifeberry, Sweet Lifeberry (L. chinense), Korean Big, N1 Lifeberry (L. truncatum) with a similarity value of 0.83 . The third cluster was the biggest one and comprised eight samples, namely, LC01-LC04, cv. Delikat (L. chinense), LB01-LB03 (L. barbarum) with a similarity value of 0.92 .

\section{Discussion}

The study of the biochemical composition of fruit plants is a very important parameter of raw plant evaluation, especially as a raw food. Fruits contain numerous compounds with different nature, structure, and nutritive value depending on the biochemical composition in its raw state (Fourie, 1996). The most important components of fruits are water, proteins, minerals, sugars, fats, and vitamins. The assessment of different characteristics, including biochemical, of fruits as well as vegetables has a practical value for human health (Wallace et al., 2020). The biochemical composition of fruits Lycium depends on many factors, such as the genetic characteristics, the maturity stage of the fruit, the cultivation in which they have been grown, soil conditions, geographic location (Niro et al., 2017). According to the literature, different environmental cultivation also influences the nutritional composition and bioactive compound of the fruits Lycium (Liu et al., 2015).

Much attention should be paid to focus on fruits' dry matter concentration, as it relates to maturity, consumer preference in itself, and flavour potential of the fruit (Harker et al., 2009; Palmer et al., 2010). Comparison with other studies showed that dry matter content for $L$. chinense was $11.9 \%$ and for $L$. barbarum 22.7-23.3\% (Dumont et al., 2020).

The sugars of many fruits and vegetables are important components of taste, play important roles in maintaining fruit commodity quality and determining nutritive value (Ashoor \& Knox, 1982; Lu \& Zhang, 2000; Gong \& Zhang, 2003; Wu et al., 2012; Zhao et al., 2015). The dominant component in the sugar profile is glucose $(152.92-284.60 \mathrm{~g} / \mathrm{kg})$, fructose $(154.20-259.13 \mathrm{~g} / \mathrm{kg})$, and lower sucrose content $(13.75-36.43 \mathrm{~g} / \mathrm{kg})$ as reported by Montesano et al. (2016) in dry fruit of $L$. barbarum marketed in China, and Zheng et al. (2010) in L. barbarum and $L$. chinense varieties cultivated in different regions in China. The main composition of Lycium sugars are sucrose, fructose, erythrose but the content of different components can change depending on the stage of growth. Content of sucrose decreased with fruit development (Zhao et al., 2015). According to Zheng et al. (2010), after blossom during 24-34 days in fruits increase of glucose and fructose level from 50 to $250 \mathrm{~g} / \mathrm{kg} \mathrm{DW}$ and decrease of sucrose from 50 to $10 \mathrm{~g} / \mathrm{kg}$ DW was noticed in the fruits. Total sugars $(350.4 \mathrm{mmol} / \mathrm{kg})$
(Mikulic-Petkovsek et al., 2012). Goji berries are mainly used in dried condition. Adiletta et al. (2015) found that, regardless of the method of drying goji fruit, the level of fructose decreased, while the content of glucose and trehalose was similar to that in fresh fruit. Genotypes with low content of sugars can be recommended for the creation of special products for diabetics. There is evidence that the sugar content varies with weather and soil conditions (Hecke et al., 2006).

Ascorbic acid is a water-soluble vitamin that plays an important role as a powerful antioxidant and is found in many biological systems. Content of vitamin $\mathrm{C}$ is one of the most valuable nutritional quality parameters of many horticultural crops and a necessary component in human vital activity (Diep et al., 2020; Kulaitiene et al., 2020). The content of this vitamin in foodstuffs and beverages is a relevant quality indicator, which can change during the storage process (Pisocschi et al., 2008). Data concerning vitamin $\mathrm{C}$ content ranged between 33.15 and $113.8 \mathrm{mg} \cdot 100 \mathrm{~g}^{-1}$, with an average value of 55. $\mathrm{mg}^{\cdot 100 \mathrm{~g}^{-1}}$ (Yossa Nzeuwa et al., 2019). Similar data found in reports by Emine Kocyigit et al. (2017) and Donno et al. (2014), while a much lower value of this parameter was determined by Cheng et al. (2015). As reported by Donno et al. (2014), vitamin C

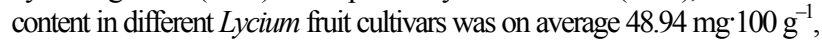
which makes up approximately $60 \%$ of the RDA. Numerous studies have reported that $L$. barbarum berries accumulated vitamin $\mathrm{C}$ in the range from 30 to $60 \mathrm{mg} \cdot 100 \mathrm{~g}^{-1} \mathrm{FW}$ (Vulić et al., 2016; Niro et al., 2017; Kafkaletou et al., 2017, 2018; Montesano et al., 2018) depending on cultivars and growing regions (Donno et al., 2014; Wojdyło et al., 2018; Kulaitiene et al., 2020). It should be noted that some studies represented vitamin C content in some goji berry varieties ten times lower than our results (Wojdyło et al., 2018; Kulaitiene et al., 2020).

Among other biologically active compounds which are contained in goji berries in the amount of $0.03-0.50 \%$ are carotenoids that possess health-promoting properties (Kulaitiene et al., 2020). $\beta$-carotene is a redorange pigment that belongs to a group of carotenoids and possess antioxidant and antiradical activity as well as ability to fight cardiovascular diseases and reduce the risk of cancer (Britton et al., 2004; Montesano et al., 2008; Mordente et al., 2011; Fattore et al., 2016). The carotenoids serve as major micronutrients in the human diet (Fraser \& Bramley, 2004; Rao \& Rao, 2007). In particular, $\beta$-carotene and $\beta$-cryptoxanthin are important components as predecessors for vitamin A biosynthesis (Weber \& Grune, 2012), while lutein and zeaxanthin slow aging-related damage to the retina (Sabour-Pickett et al., 2012). Carotenoids have been shown to be present in large quantities in fruits of $L$. barbarum (Weller \& Breithaupt, 2003; Liu et al., 2014; Montesano et al., 2020). Currently, these berries are known as the main source of zeaxanthin dipalmitate, since they represent an average of over $85 \%$ of the total carotenoids present in the fruit (Karioti et al., 2014).

Vulić et al. (2016) employed chromatographic analysis to identify and quantify carotenoids, and it was found that the content was $3.52 \mathrm{mg} \cdot \mathrm{g}^{-1}$ of methanol extract. As reported Nien-Chen et al. (2011), the carotenoids' content in goji fruit varied from 4.27 to $5.81 \mathrm{mg} \cdot \mathrm{g}^{-1}$ dry extract. Li et al. (1997) determined the B-carotene content in dry goji berry $82.2 \mathrm{mg}^{\cdot-1}$. As reported by Merzlyak et al. (2002), a positive correlation between sunlight exposure and the carotenoid concentration in the apple was found. In addition, it has been reported that exposure to high sunlight enhanced biosynthesis increased the carotenoid concentrations (De Azevedo \& Rodriguez-Amaya, 2005).

Our results on titratable acidity content were similar to those of other studies. Jatoi et al. (2018) reported that titratable acidity was between $0.90 \%$ and $0.93 \%$. In China in mature goji berries, the titratable acidity was between $0.8 \%$ and $2.7 \%$ (Zhang et al., 2016). In Greece, the majority of goji berry cultivars had titratable acidity between $2.2 \%$ and $8.3 \%$ (Drogoudi et al., 2017). In another study conducted in Greece, titratable acidity in goji berries ranged between $0.3 \%$ and $0.4 \%$ (Kafkaletou et al., 2017). The titratable acidity of the fruit is also influenced by the harvest period and the colour of the Lycium fruit. Lycium chinense fruits contain higher titratable acidity (1.6-1.9\%) than L. barbarum fruits $(0.8-1.4 \%)$. But according to the data of Polat et al. (2020), the titratable acidity content of L. barbarum fruits was significantly lower $(0.48-0.62 \%)$ than shown in from the previous study. The titratable acidity of the fruit is also related to the harvest period and the colour of the goji fruit. Thus, as reported by Ilic 
et al. (2020) in red and yellow goji fruits the titratable acidity was lower $(0.70 \%)$ than in black fruits $(0.89 \%)$. The highest titratable acidity was determined in L. barbarum fruits in September (0.84\%), while the lowest was in June $(0.36 \%)$ (Çolak et al., 2019).

The weak relationship between accumulation of studied biochemical parameters was obviously affected by different factors. As reported by Matias et al. (2016), in peach cultivars a weak correlation was found between titratable acidity and ascorbic acid. In another study, the total sugar content had a strong correlation with macro- and microelements (Dar et al., 2014)

The content of nutrients of Lycium spp. fruits can be useful for wide application in human life. Plant raw materials and different products of these species can compete with other useful fruit plants and be no less effective in various branches.

\section{Conclusions}

Thus, the investigated Lycium spp. fruits planted in Ukraine are a good source of essential nutrients such as vitamin $\mathrm{C}, \beta$-carotene content, and tannins. The findings of the present study revealed that $16 \mathrm{Lycium}$ germplasms were diverse based on biochemical assessment approaches. The results obtained will serve as a guide for the basis of genotype. Individual genotypes of 3 Lycium species: L. barbarum, L. chinense, and L. truncatum differed in investigated features. A strong positive correlation was observed only between tannin content and titratable acidity. The sugar content and titratable acidity of the fruit meet the consumer requirements for fresh fruit. The cultivar Amber Sweet (L. chinense) had fruits for which the similarities between biochemical characteristics of the different studied genotypes were the lowest. The cv. Amber Sweet was characterized by fruit with high sugar content, very high vitamin $\mathrm{C}$ content, average acid content, low tannins and $\beta$-carotene content, and the lowest dry matter content. Furthermore, a distinctive feature of the other tested genotypes was the yellow colour of the fruit,which can be used in further selective work. Also, the obtained data can be used for deep pharmacological study and possible medical purposes.

The publication was prepared with the active participation of researchers in International Network AgroBioNet within the project ITMS 25110320104 "Innovation of Test Methods and Procedures for the Detection of Sources of Bioactive Substances for the Improvement of Health and Quality of Life". The authors express their gratitude to the Visegrad Fund (52011113).

\section{References}

Adiletta, G., Alamb, M. R., Cinquanta, L., Russoc, P., Albanesea, D., Matteo, M. D. (2015). Effect of abrasive pretreatment on hot dried goji berry. Chemical Engineering Transactions, 44, 127-132.

Amagase, H., \& Farnsworth, N. R. (2011). A review of botanical characteristics, phytochemistry, clinical relevance in efficacy and safety of Lycium barbarum fruit (Goji). Food Research International, 44(7), 1702-1717.

Ashoor, S. H., \& Knox, J. M. (1982). Determination of organic acids in foods by high-performance liquid chromatography. Journal of Chromatography, 299, 288-292.

Britton, G., Liaaen-Jensen, S., \& Pfander, H. (2004). Carotenoids handbook. Birkhauser Verlag, Basel, Boston, Berlin.

Chang, J., Zhou, Z.-W., Sheng, H.-P., He, L.-J., Fan, X.-W., He, Z.-X., Sun, T., Zhang, X., Zhao, R. J., Gu, L., Cao, C., \& Zhou, S.-F. (2015). An evidencebased update on the pharmacological activities and possible molecular targets of Lycium barbarum polysaccharides. Drug Design, Development and Therapy, 9,33-78.

Chang, R. C.-C., \& So, K.-F. (2015). Lycium barbarum and human health. Springer Netherlands.

Chen, P.-Y., Shih, T.-H., Chang, K.-C., Wang, J.-S., Yang, C.-M., \& Chang, Y.-S. (2020). Potential of galled leaves of Goji (Lycium chinense) as functional food. BMC Nutrition, 6, 26.

Çolak, A. M., Okatan, V., Polat, M., \& Güçlü, S. F. (2019). Different harvest times affect market quality of Lycium barbarum L. berries. Turkish Journal of Agriculture and Forestry, 43, 326-333.

Cumaoglu, A., Bekci, H., Ozturk, E., Yerer, M. B., Baldemir, A., \& Bishayee, A. (2018). Goji berry fruit extracts suppress proliferation of triple-negative breast cancer cells by inhibiting EGFR-Mediated ERK/MAPK and PI3K/Akt signaling pathways. Natural Product Communications, 13(6), 701-706.
Dar, M. A., Wani, J. A., Raina, S. K., Bhat, M. Y., \& Malik, M. A. (2014). Relationship of leaf nutrient content with fruit yield and quality of pear. Journal of Environmental Biology, 36, 649-653.

De Azevedo, C. H., \& Rodriguez-Amaya, D. B. (2005). Carotenoid composition of kale as influenced by maturity, season and minimal processing. Science of Food and Agriculture, 85, 591-597.

Diep, T. T., Pook, C., Rush, E. C., \& Yoo, M. J. Y. (2020). Quantification of carotenoids, $\alpha$-tocopherol, and ascorbic acid in Amber, Mulligan, and Laird's large cultivars of New Zealand Tamarillos (Solanum betaceum Cav.). Foods, 9, 769.

Donno, D., Beccaro, G. L., Mellano, M. G., Cerutti, A. K., \& Bounous, G. (2014). Goji berry fruit (Lycium spp.): Antioxidant compound fingerprint and bioactivity evaluation. Journal of Functional Foods, 18, 1070-1085.

Drogoudi, P., Gerasopoulos, D., Kafkaletou, M., \& Tsantili, E. (2017). Phenotypic characterization of qualitative parameters and antioxidant contents in peach and nectarine fruit and changes after jam preparation. Journal of the Science of Food and Agriculture, 97, 3374-3383.

Dumont, D., Danielato, G., Chastellier, A., Hibrand Saint Oyant, L., Fanciullino, A.L., \& Lugan, R. (2020). Multi-targeted metabolic profiling of carotenoids, phenolic compounds and primarymetabolites in goji (Lycium spp.) berry and tomato (Solanum lycopersicum) reveals inter and intra genus biomarkers. Metabolites, 10, 422.

Emine Kocyigit, N. S. (2017). A review of composition and health effects of Lycium barbarum. International Journal of Chinese Medicine, 1(1), 1-9.

Fattore, M., Montesano, D., Pagano, E., Teta, R., Borrelli, F., Mangoni, A., Seccia, S. \& Albrizio, S. (2016). Carotenoid and flavonoid profile and antioxidant activity in "Pomodorino Vesuviano" tomatoes. Journal of Food Composition and Analysis, 53, 61-68.

Fourie, P. C. (1996). Fruit and human nutrition. In: Arthey, D., Ashurst, P. R. (Eds.). Fruit processing. Springer, Boston.

Fraser, P. D., \& Bramley, P. M. (2004). The biosynthesis and nutritional uses of carotenoids. Progress in Lipid Research, 43, 228-265.

Gong, R. G., \& Zhang, G. L. (2003). Advances in research on sugar metabolism in citrus fruit. Journal of Sichuan Agricultural University, 21, 343-346.

Grembecka, M., \& Szefer, P. (2013). Comparative assessment of essential and heavy metals in fruits from different geographical origins. Environmental Monitoring and Assessment, 185,9139-9160.

Grygorieva, O., Klymenko, S., Brindza, J., Schubertová, Z., Nikolaieva, N., \& Šimková, J. (2017). Morphometric characteristics of sweet chestnut (Castanea sativa Mill.) fruits. Potravinarstvo Slovak Journal of Food Sciences, 11(1), 288-295.

Grygorieva, O., Klymenko, S., Ilinska, A., \& Brindza, J. (2018a). Variation of fruits morphometric parameters of Elaeagnus multiflora Thunb. germplasm collection. Potravinarstvo Slovak Journal of Food Sciences, 12(1), 527-532.

Grygorieva, O., Klymenko, S., Vergun, O., Shelepova, O., Vinogradova, Y., Ilinska, A., Horčinová Sedláčková, V., \& Brindza, J. (2020). Chemical composition of leaves of Chinese quince (Pseudocydonia sinensis (Thouin) C. K. Schneid.). Agrobiodiversity for Improving Nutrition, Health and Life Quality, (4), 78-93.

Grygorieva, O., Klymenko, S., Vinogradova, Y., Vergun, O., \& Brindza, J. (2018b). Variation in morphometric traits of fruits of Mespilus germanica L. Potravinarstvo Slovak Journal of Food Sciences, 12(1), 782-788.

Grygorieva, O., Kucharska, A. Z., Piórecki, N., Klymenko, S., Vergun, O., \& Brindza, J. (2018c). Antioxidant activities and phenolic compounds in fruits of various genotypes of American persimmon (Diospyros virginiana L.). Acta Scientiarum Polonorum Technologia Alimentaria, 17(2), 117-124.

Grygorieva, O., Vergun, O., Klymenko, S., Zhurba, M., Horčinová Sedláčková, V., Ivanišová, E., \& Brindza, J. (2020). Estimation of phenolic compounds content and antioxidant activity of leaves extracts of some selected non-traditional plants. Potravinarstvo Slovak Joumal of Food Sciences, 14, 501-509.

Harker, F. R., Carr, B. T., Lenjo, M., MacRae, E. A., Wismer, W. V., Marsh, K. B., Williamsa, M., White, A., Lunda, C. M., Walkera, S. B., Gunson, F. A., \& Pereira, R. B. (2009). Consumer liking for kiwifruit flavour: A meta-analysis of five studies on fruit quality. Food Quality and Preference, 20, 30-41.

Hecke, K., Herbinger, K., Veberic, R., Trobec, M., Tolpak, H., Stampar, F., Keppel, H., \& Grill, D. (2006). Sugar-, acid and phenol contents in apple cultivars from organic and integrated fruit cultivation. European Journal of Clinical Nutritional, $60,1136-1140$

Horčinová Sedláčková, V., Grygorieva, O., Fatrcová Šramková, K., Vergun, O., Vinogradova, Y., Ivanišová, E., \& Brindza, J. (2018). The morphological and antioxidant characteristics of inflorescences within wild-growing genotypes of elderberry (Sambucus nigra L.). Potravinarstvo Slovak Journal of Food Sciences, 12(1), 444453.

Horčinová Sedláčková, V., Grygorieva, O., Vergun, O. M., Vinogradova, J. K., \& Brindza, J. (2019). Comparison of selected characteristics of cultivars and wildgrowing genotypes of Sambucus nigra in Slovakia. Biosystems Diversity, 27, $56-61$.

Illić, T., Dodevska, M., Marčetić, M., Božić, D., Kodranov, I., \& Vidović, B. (2020). Chemical characterization, antioxidant and antimicrobial properties of goji berries cultivated in Serbia. Foods, 9(11), 1614. 
Ivanišová, E., Grygorieva, O., Abrahamová, V., Schubertova, Z., Terentjeva, M., \& Brindza, J. (2017). Characterization of morphological parameters and biological activity of jujube fruit (Ziziphus jujuba Mill.). Journal of Berry Research, 7(4), 249-260.

Jatoi, M. A., Fruk, M., Buhin, J., Vinceković, M., Vuković, M., \& Jemrić, T. (2017) Effect of different storage temperatures on storage life, physico-chemical and sensory attributes of goji berry (Lycium barbarum L.) fruits. Erwerbs-Obstbau, 60(2), 119-126.

Kafkaletou, M., Christopoulos, M. V., \& Tsantili, E. (2017). Short term treatments with high $\mathrm{CO}_{2}$ and low $\mathrm{O}_{2}$ concentrations on quality of fresh goji berries ( $\mathrm{Ly}$ cium barbarum L.) during cold storage. Journal of the Science of Food and Agriculture, 97, 5194-5201.

Kafkaletou, M., Christopoulos, M. V., Tsaniklidis, G., Papadakis, I., Ioannou, D., Tzoutzoukou, C., \& Tsantili, E. (2018). Nutritional value and consumer-perceived quality of fresh goji berries (Lycium barbarum L. and L. chinense L.) from plants cultivated in Southern Europe. Fruits, 73, 5-12.

Karioti, A., Bergonzi, M. C., Vincieri, F. F., \& Bilia, A. R. (2014). Validated method for the analysis of goji berry, a rich source of zeaxanthin dipalmitate. Journal of Agricultural and Food Chemistry, 62, 12529-12535.

Klymenko, S., Grygorieva, O., \& Brindza, J. (2017). Less known species of fruit crops. Slovak University of Agriculture in Nitra, Nitra.

Klymenko, S., Kucharska, A. Z., Sokół-Łętowska, A., \& Piórecki, N. (2019). Antioxidant activities and phenolic compounds in fruits of cultivars of cornelian cherry (Cornus mas L.). Agrobiodiversity for Improving Nutrition, Health and Life Quality, 3, $484-499$.

Konarska, A. (2018). Microstructural and histochemical characteristics of Lycium barbarum L. fruits used in folk herbal medicine and as functional food. Protoplasma, 255, 1839-1854

Krischenko, V. P. (1983). Metody ocenki kachestva rastitelnoy produkcii [Methods for evaluation of quality of plant production]. Kolos, Moscow (in Russian).

Kulaitiene, J., Vaitkeviciene, N., Jariene, E., Cerniauskiene, J., Jeznach, M., \& Paulauskiene, A. (2020). Concentrations of minerals, soluble solids, vitamin C, carotenoids and toxigenic elements in organic goji berries (Lycium barbarum $\mathrm{L}$.) cultivated in Lithuania. Biological Agriculture and Horticulture, 36(2), 130-140.

Lee, H. W., Kim, Y. H., Kim, Y. H., Lee, G. H., \& Lee, M. Y. (2014). Discrimination of Lycium chinense and Lycium barbarum by taste pattern and betaine analysis. Intemational Journal of Clinical and Experimental Medicine, 7(8), 2053-2059.

Li, Z., Peng, G., Chen, L., \& Zhang, S. (1997). Determination of beta-carotene in Fructus lycii by nonaqueous reversed-phase high performance liquid chormatography. Chinese Journal of Chromatography, 15, 537-538.

Liu, Y., Lv, J., Yang, B., Liu, F., Tian, Z., Cai, Y., Yang, D., Ouyang, J., Sun, F., Shi, Y., \& Xia, P. (2015). Lycium barbarum polysaccharide attenuates type II collagen-induced arthritis in mice. International Journal of Biological Macromolecules, 78, 318-323.

Liu, Y., Zeng, S., Sun, W., Wu, M., Hu, W., Shen, X., \& Wang, Y. (2014). Comparative analysis of carotenoid accumulation in two goji (Lycium barbarum $\mathrm{L}$. and L. ruthenicum Murr.) fruits. BMC Plant Biology, 14, 269.

Lu, Y. M., \& Zhang, D. P. (2000). Accumulation of sugars in developing fruits. Plant Physiology Communications, 36, 258-265.

Luo, Q., Cai, Y., Yan, J., Sun, M., \& Corke, H. (2004). Hypoglycemic and hypolipidemic effects and antioxidant activity of fruit extracts from Lycium barbarum. Life Sciences, 76(2), 137-149.

Matias, R. G. P., Silva, D. F. P., Miranda, P. M. D., Oliveira, J. A. A., Pimentel, L. D., \& Bruckner, C. H. (2016). Relationship between fruit traits and contents of ascorbic acid and carotenoids in peach. Crop Breeding and Applied Biotechnology, 16, 348-354.

Merzlyak, M. N., Solovchenko, A. E., \& Chivkunova, O. B. (2002). Patterns of pigment changes in apple fruits during adaptation to high sunlight and sunscald development. Plant Physiology and Biochemistry, 40, 679-684

Mikulic-Petkovsek, M., Schmitzer, V., Slatnar, A., Stampar, F., \& Veberic, R. (2012) Composition of sugars, organic acids, and total phenolics in 25 wild or cultivated berry species. Journal of Food Science, 77, 1064.

Monka, A., Grygorieva, O., Chlebo, P., \& Brindza, J. (2014). Morphological and antioxidant characteristics of quince (Cydonia oblonga Mill.) and chinese quince fruit (Pseudocydonia sinensis Schneid.). Potravinarstvo Slovak Jouma of Food Sciences, 8(1), 333-340.

Montesano, D., Cossignani, L., Giua, L., Urbani, E., Simonetti, M. S., \& Blasi, F. (2016). A simple HPLC-ELSD method for sugar analysis in gojyberry. Journal of Chemistry, 2016, 6271808.

Montesano, D., Fallarino, F., Cossignani, L., Bosi, A., Simonetti, M. S., Puccetti, P., \& Damiani, P. (2008). Innovative extraction procedure for obtaining high pure lycopene from tomato. European Food Research and Technology, 226, 327-335.

Montesano, D., Juan-García, A., Mañes, J., \& Juan, C. (2020). Chemoprotective effect of carotenoids from Lycium barbarum L. on SH-SY5Y neuroblastoma cells treated with beauvericin. Food and Chemical Toxicology, 141, 111414.
Montesano, D., Rocchetti, G., Cossignani, L., Lucini, L., Simonetti, M. S., \& Blasi, F. (2018). Italian Lycium barbarum L. berry: Chemical characterization and nutraceutical value. Natural Product Communications, 13, 1151-1156.

Mordente, A., Guantario, B., Meucci, E., Silvestrini, A., Lombardi, E., Martorana, G. E., Giardina, B., \& Bohm, V. (2011). Lycopene and cardiovascular diseases: An update. Current Medicinal Chemistry, 18(8), 1146-1163.

Nien-Chen, L., Jing-Chi, L., Shih-Hsin, C., Chi-Tang, H., \& An, I. Y. (2011). Effect of Goji (Lycium barbarum) on expression of genes related to cell survival. Journal of Agricultural and Food Chemistry, 59(18), 10088-10096.

Niro, S., Fratianni, A., Panfili, G., Falasca, L., Cinquanta, L., \& Alam, M. R. (2017). Nutritional evaluation of fresh and dried goji berries cultivated in Italy. Italian Journal of Food Science, 29(3), $398-408$

Ogbonna, O. A., Ohia, G. U., Ikeyi, A. P., \& Okoye, N. H. (2016). Glycoside, moisture and dry matter composition fruits of three Musa species at three stages of development. Journal of Pharmacy and Biological Sciences, 11(3), 60-67.

Palmer, J. W., Harker, F. R., Tustin, D. S., \& Johnston, J. (2010). Fruit dry matter concentration: A new quality metric for apples. Journal of the Science of Food and Agriculture, 90(15), 2586-2594.

Pisocschi, A. M., Danet, A. F. \& Kalinowski, S. (2008). Ascorbic acid determination in commercial fruit juice samples by cyclic voltammetry. Journal of Automated Methods and Management in Chemistry, 2008, 937651.

Pleshkov, B. P. (1985). Prakticum po biohimii rasteniy [Plant biochemistry workshop]. Kolos, Moscow (in Russian).

Polat, M., Mertoglu, K., Eskimez, I., \& Okatan, V. (2020). Effects of the fruiting period and growing seasons on market quality in goji berry (Lycium barbarum L.). Folia Horticulturae, 32(2), 1-11.

Potterat, O. (2010). Goji (Lycium barbarum and L. chinense): Phytochemistry, pharmacology and safety in the perspective of traditional uses and recent popularity. Planta Medica, 76(1), 7-19.

Qian, D., Yang, J., Kang, L., Ji, R., \& Huang, L. (2017). Variation of sweet chemicals in different ripening stages of wolfberry fruits. Chinese Herbal Medicines, 9(4), 329-334.

Rao, A., \& Rao, L. (2007). Carotenoids and human health. Pharmacological Research, 55, 207-216.

Sabour-Pickett, S., Nolan, J. M., Loughman, J., \& Beatty, S. (2012). A review of the evidence germane to the putative protective role of the macular carotenoids for ge-related macular degeneration. Molecular Nutrition and Food Research, 56, 270-286.

Szot, I., Zhurba, M., \& Klymenko, S. (2020). Pro-health and functional properties of goji berry (Lycium spp.). Agrobiodiversity for Improving Nutrition, Health and Life Quality, 4, 134-145.

Tang, W. M., Chan, E., Kwok, C. Y., Lee, Y. K., Wu, J. H., Wan, C. W., Chan, R. Y. K., Yu, P. H. F., \& Chan, S. W. (2012). A review of the anticancer and immunomodulatory effects of Lycium barbarum fruit. Inflammopharmacology, 20(6), 307-314

Vinogradova, Y., Vergun, O., Grygorieva, O., Ivanišová, E., \& Brindza, J. (2020). Comparative analysis of antioxidant activity and phenolic compounds in the fruits of Aronia spp. Potravinarstvo Slovak Journal of Food Sciences, 14, 393-401.

Vulić, J. J., Čanadanović-Brunet, J. M., Ćetković, G. S., Djilas, S. M., Tumbas Saponjac, V. T., \& Stajčić, S. S. (2016). Bioactive compounds and antioxidant properties of goji fruits (Lycium barbarum L.) cultivated in Serbia. Journal of the American College of Nutrition, 35(8), 692-698.

Wallace, T. C., Bailey, R. L., Blumberg, J. B., Burton-Freeman, B., Chen, C. O., Crowe-White, K. M., Drewnowski, A., Hooshmand, S., Johnson, E., Lewis, R. Murray, R., Shapses, S. A., \& Wang, D. D. (2020). Fruits, vegetables, and health: A comprehensive narrative, umbrella review of the science and recommendations for enhanced public policy to improve intake. Critical Reviews in Food Science and Nutrition, 60(13), 217-221.

Wang, C. C., Chang, S. C., Inbaraj, B. S., \& Chen, B. H. (2010). Isolation of carotenoids, flavonoids and polysaccharides from Lycium barbarum L. and evaluation of antioxidant activity. Food Chemistry, 120(1), 184-192.

Wang, S., Suh, J. H., Zheng, X., Wang, Y., \& Ho, C. T. (2017). Identification and quantification of potential anti-inflammatory hydroxycinnamic acid amides from wolfberry. Journal of Agricultural and Food Chemistry, 65(2), 364-372.

Weber, D., \& Grune, T. (2012). The contribution of $\beta$-carotene to vitamin A supply of humans. Molecular Nutrition and Food Research, 56, 251-258.

Weller, P., \& Breithaupt, D. E. (2003). Identification and quantification of zeaxanthin esters in plants using liquid chromatography-mass spectrometry. Journal of Agricultural and Food Chemistry, 51(24), 7044-7049.

Wojdyło, A., Nowicka, P., \& Babelewski, P. (2018). Phenolic and carotenoid profile of new goji cultivars and their anti-hyperglycemic, anti-aging and antioxidant properties. Journal of Functional Foods, 48, 632-642.

Wu, B. H., Zhao, J. B., Chen, J., Xi, H. F., Jiang, Q., \& Li, S. H. (2012). Maternal inheritance of sugars and acids in peach (P. persica (L.) Batsch) fruit. Euphytica, 188, 333-345.

Xie, C., Xu, L. Z., Li, X. M., Li, K. M., Zhao, B. H., \& Yang, S. L. (2001). Studies on chemical constituents in fruit of Lycium barbarum L. China Journal of Chinese Materia Medica, 26(5), 323-324. 
Yao, R., Heinrich, M., \& Weckerle, C. S. (2018). The genus Lycium as food and medicine: A botanical, ethnobotanical and historical review. Journal of Ethnopharmacology, 212, 50-66.

Yossa Nzeuwa, I. B., Guo, B., Zhang, T., Wang, L., Ji, Q., Xia, H., \& Sun, G. (2019). Comparative metabolic profiling of lycium fruits (Lycium barbarum and Lycium chinense) from different areas in China and from Nepal. Journal of Food Quality, 2019, 1-6.
Zhang, Q., Chen, W., Zhao, J., \& Xi, W. (2016). Functional constituents and antioxidant activities of eight Chinese native goji genotypes. Food Chemistry, 200, 230-236.

Zhao, J., Li, H., Xi, W., An, W., Niu, L., Cao, Y., \& Yin, Y. (2015). Changes in sugars and organic acids in wolfberry (Lycium barbarum L.) fruit during development and maturation. Food Chemistry, 173, 718-724

Zheng, G. Q., Zheng, Z. Y., Xu, X., \& Hu, Z. H. (2010). Variation in fruit sugar composition of Lycium barbarum L. and Lycium chinense Mill. of different regions and varieties. Biochemical Systematics and Ecology, 38, 275-284. 